As regards the station tests the accuracy became very low as compaired to the expected. In contrast to that the accuracy of the field tests was in good agreement with expectation.

It was concluded that the large variance component between bulls at the stations and also the low repeatability of a station test in commercial herds are caused by a non-genetic correlation between daughters within groups. This accounts for about $2 / 3$ of the intraclass correlation between half sibs at the stations.

\title{
RELATION ENTRE LES PERFORMANCES DE REPRODUCTION ET LES PERFORMANCES D'ENGRAISSEMENT ET DE CARCASSE CHEZ LE PORC
}

\author{
C. LEGAULT. - Station de Génétique quantitative et appliquée I.N.R.A., \\ 78-Jouy-en-Josas, France.
}

Les corrélations entre les performances de reproduction (taille de la portée à la naissance et au sevrage, poids de la portée à 60 jours) de 1140 truies de race Large White et les performances d'engraissement (gain moyen quotidien de 30 à 100 kilogrammes et indice de transformation) et de carcasse (longueur, épaisseur du lard dorsal, \% de morceaux nobles et \% de morceaux gras) de 3 de leurs descendants issus de la même portée et contrôlés dans les stations de contrôle de la descendance ont été estimées. Les corrélations phénotypiques intra-verrat et station sont très faibles dans l'ensemble et non significatives. Trois coefficients dépassent cependant légèrement le seuil de signification $(p<0,05)$ : entre la longueur de la carcasse et la taille de la portée à la naissance $(r=-0,09)$ et au sevrage $(r=-0,10)$ et entre le pourcentage de morceaux nobles et le poids de la portée à 60 jours $(r=0,11)$. Les corrélations génétiques accentuent ces tendances sans qu'il soit possible de leur attribuer une valeur définitive.

En conclusion, les caractères liés à l'engraissement et à la composition corporelle sont indépendante ou faiblement associés aux performances de reproduction. Par conséquent, l'orientation actuelle de la sélection ne devrait pas, du moins à court terme, être préjudiciable à la valeur reproductive des truies.

\section{THE DESIGN OF BEEF BREED COMPARISONS}

\author{
E. P. Cunningham. - Animal Breeding \& Genetics Department, An Foras \\ Taluntais, Dublin, Eire.
}

In planning the comparison of several breeds of cattle for use as beef crossing sire lines il is necessary to decide how many bulls $(\mathrm{N})$ per breed and how many progeny $(n)$ per bull to measure. Assuming that the breeds are to be compared for a single major trait, the following seven factors need to be taken into account :

$h^{2}$ : the intrabreed heritability of the trait.

$r$ : the repeatability or accuracy of the progeny test.

$\sigma:$ the phenotypic standard deviation for the trait.

$d$ : the true difference between breeds that it is desired to detect.

$\mathrm{P}:$ the probability that a true difference of $d$ will be detected.

$p_{1}$ : the probability level at which it is desired to test the significance of a difference.

$B$ : the number of breeds to be compared.

If $h^{2}$ is presumed known, and a value is specified for $r, n$ becomes fixed. It then becomes possible to use standard experimental design theory to find the minimum value of $\mathrm{N}$ which satisfies a given difference, phenotypic standard deviation, probabilities and number of breeds. 
$\mathrm{N}$ must be found iteratively. A computer program was written to find $\mathrm{N}$ for a range of values of the various factors, and the results are presented in a table.

The use of the table can be illustrated as follows: There breeds are to be evaluated, chiefly for growth rate, which has a heritability of .3 and a phenotypic coefticient of variation of a bout 10 per cent. If the required repeatability of the progeny test is .8 , then 22 progeny per bull are needed. To have a probability of .8 of detecting a difference of 2 per cent of the mean at the .05 level will require 11 bulls per breed, or an experiment of $3 \times 11 \times 22=726$ cattle in total. With a relaxed significance level of $.10,7$ bulls per breed will suffise, requiring an experiment with $3 \times 7 \times 22=462$ cattle.

\section{DIE WIDERSTANDSF ÄHIGKEIT DER RINDERKLAUEN, EIN ÖKONOMISCHER FAKTOR DER INDUSTRIELLEN MIICH- UND FLEISCHPRODUKTION}

H. O. GRAVLR'T und s. CAMARA. - Bundesanstalt für Milch/orschung, Kiel, BRD.

Von 605 geschlachteten Rindern wurde an je 8 Klauen der Al)rieb auf einer Betonfläche bestimmt. Die Heritabilität des Abriebs betrug nur $h^{2}=0,20$, berechnet aus 30 Halbgeschwistergruppen mit 281 Jungbullen, die unter gleichen Umweltbedingungen standen. Der Abrieb war auf nassem Beton um $83 \%$ grösser als auf trockenem Beton. Der Zementanteil im Beton hatte keinen Einfluss, die Korngrösse der Beimengungen nur einer geringen. Dagegen wirkte sich die Struktur der Beimengungen wesentlich aus, $z$. B. war der Abrieb auf Tuffstein etwa doppelt so gross wie auf Quarzsand. Eine Behandlung der Klauen mit Formalin oder Branntkalk reduzierte den Abrieb um 6 bzw. $24 \%$. - Die experimentellen Ergebnisse konnten in Versuchen mit lehenden Kühen in der Tendenz bestätigt werden. 